\title{
SIDE EFFECTS OF DIETHYLSTILBESTROL (DES) FROM THE PERSPECTIVE OF TORT LAW
}

DOI: 10.36740/WLek202012240

\author{
Bohdan P. Karnaukh', Artem R. Shymko ${ }^{2}$ \\ ${ }^{1} Y$ AROSLAV MUDRYI NATIONAL LAW UNIVERSITY, KHARKIV, UKRAINE \\ 2POLTAVA LAW INSTITUTE OF YAROSLAV MUDRYI NATIONAL LAW UNIVERSITY, POLTAVA, UKRAINE
}

\begin{abstract}
The aim of the article is to analyze the reasoning of the Supreme Court of California in Sindell v. Abbott Laboratories.

Materials and methods: Materials of the study encompass US case law as well as case law of other countries concerning compensation of damage caused by defective drugs and other cases of uncertain causation. The survey is conducted within the framework of comparative law studies. In addition, elements of law and economics approach are also employed in the paper.

Conclusions: Case of Sindell v. Abbott Laboratories has launched a new direction in discourse on causation in tort law and product liability. The mathematical elegance of the Court's theory is that net burden of liability borne by a particular drug manufacturer is equal to the amount of damage actually caused by its drug.
\end{abstract}

KEY WORDS: diethylstilbestrol (DES), alternative liability, toxic tort, causation, market share liability

Wiad Lek. 2020;73(12 p. II):2946-2950

\section{INTRODUCTION}

Tort law is based on the principle of personal liability: the damage must be reimbursed by the person who caused it. The obligation to compensate cannot be imposed on a person until it has been proven that the actions of that person were the legal cause of the damage. During the trial the burden of proving that it was the defendant who caused the damage rests with the plaintiff [1, p. 1602; 2, p. 324]. Therefore, if the plaintiff fails to discharge his burden of proof, court rules in favor of the defendant.

However, there are some cases where discharging the said burden of proof appears to be impossible due to the factors for which the plaintiff cannot be blamed. These cases are commonly referred to as cases of "uncertain causation" (See: [3-9]) or "toxic torts" (See: [10-12]) $)^{1}$. Among them there are cases where a person sustains injuries as a result of ingesting dangerous defective drug manufactured according to one and the same formula by a number of pharmaceutical companies. Due to the passage of time evidence (pertaining the brand of the drug taken) may become unavailable or unreliable and therefore the person may be unable to identify the pharmaceutical company that produced the pills and thus caused the damage which is sought to be compensated. Under these circumstances the courts encounter the dilemma either to follow the established rules on causation and leave the injured person uncompensated or to fashion a new approach that would satisfy the intuitive sense of justice and allow for compensation in the perplexed cases of uncertain causation.

\section{THE AIM}

The aim of the article is to analyze the decision of the Supreme Court of California in a prominent case relating to the injuries caused by a defective drug which manufacturer cannot be identified.

\section{MATERIALS AND METHODS}

Materials of the study encompass US case law as well as case law of other countries concerning compensation of damage caused by defective drugs and other cases of uncertain causation. The survey is conducted within the framework of comparative law studies. In addition, elements of law and economics approach are also employed in the paper.

\section{REVIEW AND DISCUSSION}

From 1941 to 1971, the drug diethylstilbestrol (DES) was sold on the American market. It is a synthetic substitute for the female hormone estrogen. Doctors prescribed it to pregnant women to prevent miscarriage [14]. However, it was later found that DES is a carcinogen and can cause malignant tumors (including adenocarcinoma) of the genitals in female children whose mothers took the drug during pregnancy [15, p. 964-965]. The cancer provoked in this way has a latent period no less than 10-12 years [14].

In total, during the said period, 1.5 to 3 million women were administred the drug [14]. So probably hundreds, or

${ }^{1}$ Pesticides are also among the dangerous toxic substances that can cause actionable damage. On the international legislation see: [13]. 
even thousands, of their daughters have developed malignant tumours. One of the victims was Judith Sindell. As a result of her mother's taking DES while being pregnant, Ms. Sindel developed a malignant bladder tumor. On this basis she applied to court claiming damages.

Decision of the Supreme Court of California in the case of Sindell v. Abbott Laboratories, not to exaggerate, became a new milestone in the evolution of modern tort law [16-22].

Since the case concerned damage caused by a defective product, the plaintiff had to prove not only that the damage was caused by the defective drug, but also that the drug was manufactured by no other than the defendant. In this regard, Judith Sindell encountered an insurmountable obstacle: DES is a generic formula and more than two hundred pharmaceutical companies used it to produce the drug.

When prescribing the drug, physicians did not specify a particular brand, because drugs from different manufacturers were therapeutically equivalent and interchangeable. In addition, it has been more than twenty years since Ms. Sindell's mother took DES, so it was no longer possible to identify the exact brand of the pills her mother took.

Therefore, Ms. Sindell filed a lawsuit against eleven pharmaceutical companies, which at the time of her mother's pregnancy produced a total of $90 \%$ of the DES on the market. Three concepts were invoked to substantiate the claim: alternative liability, concert of action and industry-wide liability.

The concept of alternative liability is represented by the case of Summers $v$. Tice [23] the facts of which are also known as two hunters dilemma ${ }^{2}$. In this case, two hunters acting negligently fired in the same direction. As it turned out, the shot hit the third hunter. But it was impossible to identify whose pellets hit the victim, since the hunters used the same rifles and the same pellets. The court held that in such circumstances both hunters should be jointly and severally liable for the damage caused. To be precise, the Court ruled that the burden of proof should be reversed and it is not the plaintiff who has to identify the defendant whose pellet caused damage, but instead it is each of the defendants who has to prove that it was not his pellet that caused the damage. And since the defendants in Summers were not able to identify the origin of the pellet, the court found them jointly and severally liable for the damage [23].

In Sindell the applicability of the said concept was denied $^{3}$. The Court pointed out that in order to apply alternative liability, everyone who could be the culprit of the damage has to appear before the court. In other words, a guarantee is needed that the person who actually caused the damage is among the defendants brought to trial. This was the case in Summers, where both hunters were brought to court. Ms. Sindell, on the other hand, filed a lawsuit against only a small portion (eleven of the more than two hundred) of the pharmaceutical companies that manufactured DES. Thus, it is possible that the company, whose pills were actually taken by the plaintiffs' mother, was not present at all among the cohort brought to trial. In such circumstances, to impose joint and several liability (as the Summers case provides) on defendants in respect of whom there is no guarantee that any of them has actually caused harm seems to be an unfairly broad interpretation of alternative liability doctrine.

Secondly, the plaintiff asserted that the damage was caused by the defendants acting in concert $^{4}$ (since, if the damage was caused by the joint actions of several persons, they are jointly and severally liable for it and thus there is no need to identify which of the defendants produced the exact pills Ms. Sindell's mother took and which was involved in some other way, e.g. by promoting or advertising DES). According to the plaintiff, the concert of actions consisted in all the defendants relying on each other's clinical trials (on drug safety) and benefiting from each other's marketing strategies to promote the drug on the market.

This argument was based, in particular, on the special rules governing the production and marketing of the drugs in the United States. Thus, according to the legislation in force at the time, as long as a certain drug is not "generally recognized as safe", every company that intends to produce it must apply to the Food and Drug Administration (FDA). Accordingly, production can be started only if the application is approved by the FDA. But as soon as the FDA assigns a drug the status of "generally recognized as safe", it can be manufactured by anyone without the need for prior application. Until 1952, when DES was granted the status of "generally recognized as safe", applications for its production were submitted 123 times [14].

In this context, the plaintiff's argument probably should be interpreted as follows. All companies that applied to FDA to approve DES's safety and efficacy thereby contributed to the drug being given the status of "generally recognized as safe", which resulted in its further spreading on the market and increasing the number of its manufacturers.

All the DES-manufacturers did act in a similar way to some extent. But is this similarity enough to prove they acted in concert? The court answered this question in the negative. For a court to find concert of action, there must be an express agreement or tacit understanding between the actors, and everyone has to realize the wrongfulness of the other's actions. In the Court's view, the plaintiff had not proved it.

That there is a certain pattern traced in all the defendants' course of actions - it is due to the fact that the market of drugs is thoroughly regulated and pharm companies just followed the established procedures. Manufacturers should not be accused of conspiracy on the sole ground that they all operate under the same regulatory standards. Otherwise, it would mean that within some industry, each

\footnotetext{
${ }^{2}$ Comments on the case see: [24; 25].

${ }^{3}$ Comments on the applicability of alternative liability in Sindell see: [15, p. 985-995; 26, p. 788-791; 27, p. 156-158].

${ }^{4}$ Comments on the argument see: [15, p. 978-985; 26, p. 792; 27, p. 150-151].
} 
manufacturer can be held liable for damage caused by a defective product of another manufacturer solely on the ground that it operates on the same market and thus takes part in the promotion of the similar product.

Finally, to substantiate her claim, the plaintiff resorted to so called industry-wide liability. In particular, she referred to the case of Hall v. E. I. Du Pont de Nemours \& Co., Inc. [28]. In this case, there were 12 incidents where children were injured by explosions of blasting caps, and it was impossible to determine which company produced the particular cap. The Court ruled that all six companies that constituted the entire blasting cap industry should be held liable. The decision was grounded on the fact that the companies did pursue a coordinated safety and labeling policy. Moreover, significant part of the safety functions was delegated by all industry members to an association called the Institute of Makers of Explosives.

In Sindell the Court rejected this argument as well ${ }^{5}$, stating that the application of industry-wide liability requires that all industry participants exercise joint control over the risks. That is, the product safety standards must be set by the agreement of all manufacturers compounding the industry. And so it was with Hall, because the requirements for labeling and design were set by an association voluntarily formed by the manufacturers. Thus, each of the manufacturers was involved in fashioning product safety standards. In contrast, in the pharmaceutical industry, safety standards are set by a government body, namely the FDA. Therefore, the risks are controlled more by the FDA, rather than by each manufacturer individually or by all manufacturers together.

In addition, while industry-wide liability is appropriate for centralized industries with a small number of manufacturers, its application is hard to justify in a case of a decentralized industry with several hundred manufacturers, as was the case in Sindell.

Having concluded that neither of three doctrines pleaded by the defendant solve the problem, the Supreme Court of California developed a new doctrine named market share liability (hereinafter - MSL).

The Court held that, provided the plaintiff brings to court manufacturers whose aggregate market share in the product is considered substantial, each of those manufacturers should compensate for the damage caused by the product in proportion to its own market share in that product. Thus, if damages amount to 1 million USD and the defendant's market share is $30 \%$, that defendant has to pay the plaintiff 300,000 USD (unlike in Summers, where the hunters' liability was joint and several). That is so because the manufacture's market share indicates the probability of this manufacture's product being the actual cause of the damage [26, p. 798; 27, p. 158].

The mathematical elegance of MSL doctrine is that ultimately the net burden of liability that falls on a particular pharm company is equal to the net amount of damage caused by that particular company. Therefore, application of MSL in long run results in the same allocative effects that would have been achieved provided the full knowledge (as to the identity of the manufacturer in each particular case) and application of the regular requirements for proof of causation: plaintiffs receive exactly the same compensation, and defendants bear exactly the same burden of liability.

According to Sindell, the plaintiff does not have to sue all the drug manufacturers - it is enough to sue manufacturers whose aggregate market share is substantial. There are two ways to treat Sindell decision with regard to the allocation of liability between the defendants [27, p. 162-163; 29, p. $941 ; 30$, p. 89, 105].

First, the companies brought to court reimburse the plaintiff only the portion of damages corresponding to their aggregate market share. Second, the companies brought to court reimburse the plaintiff's damages in full, thus covering also the portion that must have been borne by the companies not sued by the plaintiff.

Judge Richardson, in his dissenting opinion, interprets the majority's conclusion in the letter way, noting that "those defendants who are brought to trial in this state will bear effective joint responsibility for 100 percent of plaintiffs' injuries despite the fact that their "substantial" aggregate market share may be considerably less" [14].

In addition, the decision of the majority inter alia states that the defendants against whom the lawsuit is filed have the right to involve other co-defendants (cross-complain). However, such a right is of value to the defendant only if he is able to reduce his own liability by involving another defendant. If the amount of liability depends only on the defendant's market share and does not depend on the number of defendants before the court - it does not make sense for the defendants brought to court to possess such a right [27, p. 162-163].

This interpretation effectively means that the risk of insolvency, liquidation or other events that render a company unreachable for a lawsuit - rests with the companies that hold up well at the time the plaintiff learns about the injury. Of course, for the plaintiffs this interpretation has an obvious advantage, as they avoid undercompensation. However, the overall allocative effect of such an interpretation cannot be considered optimal, as the net burden of liability borne by each manufacturer exceeds the amount of damage it actually caused. From a legal point of view, this seems unfair, since manufactures appear to be treated unequally. From an economic point of view, this will negatively affect the manufactures' interest in carrying out the relevant activities and may result in underproduction. This second, economic argument is particularly important because much of the Sindell's criticism is based on the assertion that MSL places an excessive burden of responsibility on pharmaceutical manufacturers, and this burden will discourage them from investing in the development, research, and production of new drugs (which, of course, would entail large-scale public losses). 
In particular, this point was made by Justice Richardson. In his dissenting opinion he stated:

"It seems to me that liability in the manner created by the majority must inevitably inhibit, if not the research or development, at least the dissemination of new pharmaceutical drugs. <...> I also suggest that imposition of so sweeping a liability may well prove to be extremely shortsighted from the standpoint of broad social policy. $<\ldots\rangle$ It is counterproductive to inflict civil damages upon all manufacturers for the side effects and medical complications which surface in the children of the users a generation after ingestion of the drugs, particularly when, at the time of their use, the drugs met every fair test and medical standard then available and applicable. Such a result requires of the pharmaceutical industry a foresight, prescience and anticipation far beyond the most exacting standards of the relevant scientific disciplines. In effect, the majority requires the pharmaceutical research laboratory to install a piece of new equipment - the psychic's crystal ball" [14].

In this context, Robert A. Kors believes that Sindell decision has another flaw, that potentially may lead to the net burden of manufacturer's liability being larger than the amount of damage actually caused by it [29, p. 938-939, 942]. While Sindell sets forth MSL, the victim, who can accurately identify the manufacturer (if prescriptions, receipts, checks, etc. miraculously survived), still has the right to claim damages in full from this particular manufacturer on the basis of general rules for proving causation. It means that any given manufacturer may be sued both on the ground of general rules and on the ground of MSL doctrine.

However, the equation between the net burden of liability and the net amount of damage caused by a manufacturer will not be distorted given that the ratio between individualized claims (to each of the manufacturers) replicates the ratio between market shares of the respective manufacturers. And since it seems plausible, the availability of individualized claims will not make a significant difference regarding the correspondence of net liability to net damage caused by each manufacturer.

However, the same cannot be said of the Sindell's interpretation, according to which the companies brought to court have to distribute among themselves the share of damages that would have fell on the companies that did not appear in court. Such an interpretation will always result in a disproportion between the burden of liability and the amount of damage caused.

Lastly, it should be mentioned that after Sindell there were a number of attempts to apply the MSL doctrine to substances other than DES. In particular, to asbestos, silicone implants, lead paints, donor blood, latex gloves, tobacco products, pesticides and methyl tert-butyl ether (MTBE) which polluted groundwater (see: [31-37]). And though not all the attempts have been successful, there is no denying that the Sindell case paved the way for a brand new perspective on the issue of uncertain causation and inspired scholars and judges around the world to further elaborate on the issue.

\section{CONCLUSIONS}

Case of Sindell v. Abbott Laboratories has launched a new direction in discourse on causation in tort law and product liability. The California Supreme Court has ruled that the inability to identify a defendant should not be an insurmountable barrier that prevents a victim of a dangerous drug from obtaining compensation. The mathematical elegance of the Court's theory is that net burden of liability borne by a particular drug manufacturer is equal to the amount of damage actually caused by its drug. This means that, theoretically in long run the distributive effects of market share liability are the same as they would have been had the complete knowledge been available and each victim been able to identify the brand of the drug her mother ingested.

\section{REFERENCES}

1. Oliphant, K. Uncertain Factual Causation in the Third Restatement: Some Comparative Notes. William Mitchell Law Review. 2011;37:1599-1632.

2. Van Dam, C. European Tort Law (2nd ed.). Oxford: Oxford University Press, 2013, $324 \mathrm{p}$.

3. Adeney, E. The Challenge of Medical Uncertainty: Factual Causation in Anglo-Australian Toxic Tort Litigation. Monash University Law Review. 1993; 19:23-67.

4. Franzoni, L.A. Liability Law under Scientific Uncertainty. American Law and Economics Review. 2017; 19:327-360.

5. Graziano, T.K. (2008). 'All or Nothing' or Partial Liability in Cases of Uncertain Causation. European Review of Private Law. 2008; 6:1009-1042.

6. Martín-Casals, M. \& Papayannis, D.M. (Eds). Uncertain Causation in Tort Law. Cambridge: Cambridge University Press, 2016, 333 p.

7. Porat, A. \& Stein, A. Tort Liability under Uncertainty. Oxford: Oxford University Press, 2001, xii, $206 \mathrm{p}$.

8. Steel, S. \& Ibbetson, D. More Grief on Uncertain Causation in Tort. Cambridge Law Journal. 2011; 70:451-468.

9. Weinrib, E.J. Causal Uncertainty. Oxford Journal of Legal Studies. 2016; 36:135-164.

10. Blomquist, R.F. Emerging Themes and Dilemmas in American Toxic Tort Law, 1988-91: A Legal-Historical and Philosophical Exegesis. Southern Illinois University Law Journal. 1993; 18:1-119.

11. Farber, D.A. Toxic Causation. Minnesota Law Review. 1978; 71:1219-1261.

12. Kanner, A. Toxic Tort Litigation in a Regulatory World. Washburn Law Journal. 2002; 41:535-548.

13. Pashkov, V., Batyhina, 0. , Trotska, M. Legal Restraints of Pesticide Effect on Human Organism and Environment under International Legislation. Wiadomości Lekarskie. 2017; 70(2):366-371.

14. Sindell v. Abbott Laboratories, 1980.26 Cal. 3d 588.

15. Sheiner, N. DES and a Proposed Theory of Enterprise Liability. Fordham Law Review. 1978; 46(5): 963-1007.

16. Koperski, B.J. Market Share Liability for DES (Diethylstillbestrol) Injury: A New High Water Mark in Tort Law: Sindell v. Abbott Laboratories. Nebraska Law Review. 1981; 60(2):432-449.

17. Market Share Liability: An Answer to the DES Causation Problem. Harvard Law Review. 1981; 94(3):668-680.

18. Morgan, E. Market Share Liability for Injurious Products: A Comment on Sindell. University of Toronto Faculty of Law Review. 1983; 41:52-62.

19. Market Share Liability Adopted to Overcome Defendant Identification Requirement in DES Litigation, Sindell v. Abbott Laboratories. Washington University Law Quarterly. 1981; 59(2): 571-584. 
20. Redemann, B.B. Manufacturers' Liability Based on a Market Share Theory: Sindell v. Abbott Laboratories. Tulsa Law Journal. 1980; 16(2):286-316.

21. Sheffet, M. J. Market Share Liability: A New Doctrine of Causation in Product Liability. Journal of Marketing. 1983; 47(1):35-43.

22. Taylor, N.D. California Expands Tort Liability under the Novel Market Share Theory: Sindell v. Abbott Laboratories. Pepperdine Law Review. 1981; 8:1011-1043.

23. Summers v. Tice, 1948. 33 Cal.2d 80, 199 P.2d 1.

24. Karnaukh, B. Neziasovna prychynnist: dylema dvokh myslyvtsiv [Uncertain Causation: Two Hunters Dilemma] Problems of Legality. 2020; 149: 49-61 doi: 10.21564/2414-990x.149.196945 (Ua).

25. J. Neethling, The Case of the Three Hunters, or Delictual Liability for Alternative Causes. The South African Law Journal. 2003; 120:263-268.

26. Madden, M.S. \& Holian, J. Defendant Indeterminacy: New Wine into Old Skins. Louisiana Law Review. 2007; 67(3):785-822.

27. Marshack, R.A. Sindell v. Abbott Laboratories: Is Market Share Liability the Best Remedy to the DES Controversy. California Western Law Review. 1982; 18:143-177.

28. Hall v. E. I. Du Pont de Nemours \& Co., Inc. 345F. Supp. 353 (E.D.N.Y. 1972).

29. Kors, R.A. Refining Market Share Liability: Sindell v. Abbott Laboratories. Stanford Law Review. 1981; 33:937-950.

30. Miller, K.C. \& Hancock, J.D. Perspectives on Market Share Liability:Time for a Reassessment. West Virginia Law Review, 1985; 88:81-112.

31. Damorn, E.H. Reviving the Market for Liability Theories: The Commingled Product Theory of Market Share Liability Enters the Judicial Lexicon. Pennsylvania State Law Review. 2006; 111:505-525.

32. Gifford, D.G. and Pasicolan, P. Market Share Liability Beyond DES Cases: The Solution to the Causation Dilemma in Lead Paint Litigation. South Carolina Law Review. 2006; 58:115-159.

33. Giliberti, F.J. Emerging Trends for Products Liability: Market Share Liability, Its History and Future. Touro Law Review. 1999; 15:725-734.

34. Greer, B.T. Market Share Liability Shouldn't Die: Proposed Application to Agricultural Pesticides and the Need to Refine the Apportionment of Liability. San Joaquin Agricultural Law Review. 2007; 17:85-108.
35. Lawson, S. The Conundrum of Climate Change Causation: Using Market Share Liability to Satisfy the Identification Requirement in Native Village of Kivalina v. Exxonmobil Co. Fordham Environmental Law Review. 2011; 22:433-492.

36. Perillo, L.A. Scraping beneath the Surface: Finally Holding Lead-Based Paint Manufacturers Liable by Applying Public Nuisance and MarketShare Liability Theories. Hofstra Law Review. 2004; 32:1039-1093.

37. Rostron, A. Beyond Market Share Liability: A Theory of Proportional Share Liability for Nonfungible Products. UCLA Law Review. 2004; 52:151-215.

\section{ORCID and contributionship:}

Bohdan P. Karnaukh: 0000-0003-1968-3051 A,D,F

Artem R. Shymko: ORCID 0000-0002-7153-4929 B,D,E

\section{Conflict of interest:}

The Authors declare no conflict of interest.

\section{CORRESPONDING AUTHOR Bohdan P. Karnaukh \\ Yaroslav Mudryi National Law University, \\ Department of Civil Law No.1, Pushkinskaya str., 77, 61024, Kharkiv, Ukraine tel: +380997147757 \\ e-mail:karnaukh.bogdan@gmail.com}

Received: 25.08 .2020

Accepted: 26.11 .2020

A - Work concept and design, B - Data collection and analysis, C - Responsibility for statistical analysis, D-Writing the article, $\mathbf{E}$-Critical review, $\mathbf{F}$ - Final approval of the article 